\title{
Developing Ideal Leadership Perception of Accounting Students Through The 360 Degrees Leadership Education
}

\author{
Hanny. ${ }^{1}$, Nunik Lestari Dewi ${ }^{2}$, Sinta Setiana ${ }^{3}$, Meliana Halim ${ }^{4}$ \\ Program Studi Akuntansi, Universitas Kristen Maranatha, Bandung, Indonesia 1,2,3,4 \\ Email: sevenhanny@gmail.com
}

\begin{tabular}{|c|c|}
\hline INFO ARTIKEL & ABSTRAK/ABSTRACT \\
\hline $\begin{array}{l}\text { Histori Artikel : } \\
\text { Tgl. Masuk : 13-12-2021 } \\
\text { Tgl. Diterima : 23-02-2021 } \\
\text { Tersedia Online : 31-03-2021 } \\
\text { Keywords: } \\
360 \text { Degree Leadership Education; } \\
\text { Leadership Perception; Accounting } \\
\text { Students. }\end{array}$ & $\begin{array}{l}\text { This study aims to determine the effect of } 360 \text { Degree } \\
\text { Leadership Education on the perception of Accounting } \\
\text { Students about the ideal leadership principles and to } \\
\text { analyze the difference of the Accounting student's } \\
\text { leadership perception before and after got this education. } \\
\text { We hope that this study can contribute to support the } \\
\text { Accounting Profession to have the professional } \\
\text { Accountants who deserve to lead this profession in time to } \\
\text { come. } \\
\text { The research data were obtained through some } \\
\text { questionnaires that have been distributed to } 100 \text { students } \\
\text { who haven't got the } 360 \text { Degree Leadership Education and } \\
\text { 100 other students who have got it in } 2019 \text {. We used Non- } \\
\text { Probability Sampling with the Purposive Sampling Method } \\
\text { to get representative sample. We also used the descriptive } \\
\text { analysis, Simple Linear Regression, and the comparative } \\
\text { hypothesis testing to test the hypothesis. } \\
\text { The results show that the } 360 \text { Degree Leadership } \\
\text { Education influences the leadership perception of the } \\
\text { Accounting students by } 27.5 \% \text {. This research indicates that } \\
\text { there is different leadership perception between these two } \\
\text { groups of students. Furthermore, it shows that the } \\
\text { Accounting student who haven't got the } 360 \text { Degree } \\
\text { Leadership Course tend to agree with the myth of } \\
\text { leadership while the other students who have got it show the } \\
\text { opposite tendency. }\end{array}$ \\
\hline
\end{tabular}

\section{PENDAHULUAN}

Saat ini Era Revolusi Industri 4.0 sedang berlangsung, dimana perusahaan dihadapkan dengan sistem digital dan otomatisasi. Untuk dapat beradaptasi dengan kondisi dunia usaha di era tersebut, perusahaan harus memenuhi beberapa persyaratan, diantaranya adalah bidang sumber daya manusia, baik dari segi keterampilan (skill) maupun dari segi pendidikan berkelanjutannya (Rojko, 2017). Di bidang sumber daya manusia, perusahaan membutuhkan tenaga kerja yang dilengkapi dengan pengetahuan serta keterampilan yang berbeda dari era revolusi industri sebelumnya dan yang semakin relevan dengan tuntutan Era Industri 4.0, termasuk kebutuhan akan sumber daya di bidang akuntansi. Program Studi Akuntansi perlu merespon kebutuhan ini melalui pembaharuan kurikulumnya dan sistem pengajarannya supaya dapat membekali akuntan profesional dengan keterampilan yang dibutuhkan di Era Revolusi Industri 4.0 (Stanciu \& Bran, 2015).

Salah satu keterampilan yang harus dimiliki oleh seorang lulusan program studi Akuntansi di era revolusi industri saat 4.0 
ini adalah keterampilan di bidang kepemimpinan (leadership skills) (Mayasari, Anjelina, \& Irsutami, 2020). Keterampilan kepemimpinan (leadership skills) merupakan kemampuan seseorang untuk mendorong/mempengaruhi orang lain agar dapat berkontribusi dalam misi pencapaian tujuan (Copeland, 2015). Menurut Ikatan Akuntan Indonesia (IAI), Hanya sosok akuntan profesional yang memiliki keterampilan kepemimpinan inilah yang layak memimpin profesi ini di masa depan. Dalam hal ini, akuntan profesional perlu mengkombinasikan kemampuan dasar di bidang akuntansi dengan keterampilan di bidang kepemimpinan agar profesionalisme mereka sebagai akuntan dapat dianggap eligible saat mengisi posisi kepemimpinan dimanapun mereka berkarir (IAI, 2015). Sebuah penelitian terdahulu juga menunjukkan bahwa gaya kepemimpinan seorang akuntan yang berkarir sebagai seorang auditor berpengaruh secara signifikan dan positif terhadap kinerja auditor (Arifah, 2012). Tak heran jika keterampilan para akuntan di bidang kepemimpinan dianggap mampu mengangkat wibawa profesinya di mata publik terlepas dimanapun mereka berkarir (IAI, 2015). Berangkat dari pernyataan di atas, maka mahasiswa program studi Akuntansi selaku calon para Akuntan Profesional masa depan jelas perlu dibekali dengan keterampilan dalam memimpin (leadership skills).

Sebuah hasil penelitian menunjukkan bahwa dalam mengembangan sebuah keterampilan kepemimpinan mahasiswa, pembentukan pola pikir/persepsi mereka tentang kepemimpinan merupakan hal yang penting (Bloch, Brewer, \& Stout, 2012). Untuk itu, sebuah prinsip kepemimpinan yang ideal perlu menjadi dasar persepsi kepemimpinan mereka. Penelitian ini menggunakan PrinsipPrinsip Kepemimpinan 360 Derajat (The 360-Degree Leadership Principles) yang dikembangkan oleh John Calvin Maxwell sebagai prinsip-prinsip kepemimpinan yang ideal. Alasannya adalah bahwa prinsip-prinsip dari gaya Kepemimpinan 360 Derajat ini dianggap mampu mematahkan mitos yang berkaitan dengan kepemimpinan dan dapat diterapkan oleh siapapun yang berniat menjadi seorang pemimpin sejati tanpa melihat posisi mereka di dalam organisasi (Maxwell, 2012). Hingga saat ini, masih jarang ditemukan penelitian yang menganalisis metode yang efektif untuk mengembangkan mahasiswa di bidang keterampilan kepemimpinan (khususnya di bidang akuntansi) dengan cara membentuk persepsi mereka akan kepemimpinan yang ideal menurut prinsip Kepemimpinan 360 Derajat ini. Untuk itu penelitian ini dilaksanakan dengan tujuan untuk menganalisis pengaruh Pendidikan Kepemimpinan 360 Derajat yang diterapkan di Program Studi Akuntansi terhadap pembentukan persepsi mahasiswa Akuntansi mengenai prinsip kepemimpinan yang ideal. Tujuan lain dari penelitian ini adalah menganalisis perbedaan persepsi kepemimpinan antara mahasiswa akuntansi yang belum mengenyam pendidikan Kepemimpinan 360 Derajat ini dan mahasiswa akuntansi yang telah mengenyam pendidikan Kepemimpinan 360 Derajat ini. Adapun rumusan masalah dari penelitian ini adalah sebagai berikut:

1. Apakah terdapat pengaruh pendidikan Kepemimpinan 360 Derajat terhadap pembentukan persepsi Kepemimpinan 360 Derajat mahasiswa akuntansi?

2. Apakah terdapat perbedaan pembentukan persepsi Kepemimpinan 360 Derajat antara mahasiswa akuntansi yang belum menempuh pendidikan Kepemimpinan 360 Derajat dan mahasiswa akuntansi yang telah menempuh pendidikan kepemimpinan tersebut?

\section{KERANGKA TEORITIS DAN PENGEMBANGAN HIPOTESIS}

\section{Keterampilan Akuntan Profesional Di Era Industri 4.0}

Salah satu keterampilan yang harus dimiliki oleh seorang lulusan program studi Akuntansi di Era Revolusi Industri 4.0 ini adalah keterampilan di bidang kepemimpinan (Mayasari et al., 2020). Keterampilan ini merupakan kemampuan seseorang untuk mendorong/ 
mempengaruhi orang lain agar dapat berkontribusi dalam misi pencapaian tujuan (Copeland, 2015). Sebuah penelitian terdahulu menunjukkan bahwa gaya kepemimpinan seorang akuntan yang berkarir sebagai seorang auditor berpengaruh secara signifikan dan positif terhadap kinerja auditor (Arifah, 2012). Berangkat dari pernyataan di atas, maka mahasiswa program studi Akuntansi selaku calon Akuntan Profesional masa depan jelas perlu dibekali dengan keterampilan dalam memimpin (leadership skills).

\section{Persepsi Kepemimpinan Mahasiswa Akuntansi}

Penelitian (Bloch, Brewer, \& Stout, 2012) menunjukkan bahwa di dalam upaya pengembangan keterampilan kepemimpinan mahasiswa, pembentukan pola pikir mereka tentang kepemimpinan merupakan suatu hal yang penting. Hal ini dikarenakan pola pikir mahasiswa akan mempengaruhi persepsi mereka tentang kepemimpinan (Keller \& Gollwitzer, 2017).

Memiliki persepsi yang benar tentang kepemimpinan yang ideal merupakan keterampilan yang sangat signifikan dalam menciptakan kepemimpinan yang efektif (Otara, 2011). Dengan kata lain, untuk membekali mahasiswa Akuntansi dengan keterampilan kepemimpinan yang ideal, maka mereka perlu memiliki persepsi yang benar tentang prinsip kepemimpinan yang ideal.

Membentuk persepsi kepemimpinan mahasiswa akuntansi yang benar ini, tentu menjadi sebuah tantangan tersendiri bagi perguruan tinggi yang selama ini menjadi Lembaga pendidikan formal bagi mahasiswa akuntansi. Dosen harus belajar lebih dari sekedar mengajar. la harus menjadi seorang fasilitator, memberikan praktik kepada mahasiswa, memberikan tanggungjawab pribadi untuk pertumbuhan, membangun komunitas belajar yang lebih inklusif (Komives et al, 2007 dalam (Rosch \& Anthony, 2012)), Dengan demikian, maka pendidikan kepemimpinan akan mampu mengembangkan sikap, pengetahuan dan keterampilan terkait perilaku kepemim- pinan mahasiswa akuntansi (Rosch \& Anthony, 2012).

Mengingat begitu banyak prinsip kepemimpinan yang ada di muka bumi ini maka penelitian ini mengusung Prinsip Kepemimpinan 360 Derajat (360-Degree Leadership Principles) dari John Calvin Maxwell sebagai prinsip kepemimpinan yang ideal. Alasannya adalah bahwa prinsip-prinsip dari gaya Kepemimpinan 360 Derajat ini dianggap mampu mematahkan mitos yang berkaitan dengan kepemimpinan (Maxwell, 2012). Mitos kepemimpinan yang dimaksud oleh Maxwell (2012) meliputi pemikiran yang menyatakan: (1) seseorang tidak dapat memimpin orang lain kecuali jika ia memiliki jabatan tinggi dalam organisasi. (2) Seseorang juga baru mampu belajar untuk memimpin orang lain jika ia sudah berhasil duduk di puncak pimpinan. (3) Seseorang tidak akan memiliki niat untuk mencoba memimpin jika belum menduduki posisi atas di dalam perusahaan. (4) Saat seseorang berhasil menjabat di posisi atas, maka ia baru akan memegang kendali dan orang lain akan mengikutinya. (5) Seseorang harus meraih jabatan tertinggi dalam organisasi untuk mencapai potensinya. (6) dan ketika seseorang berhasil meraih posisi tertinggi maka ia tidak akan dibatasi lagi.

Alasan lain yang mendasari Prinsip Kepemimpinan 360 Derajat (360-Degree Leadership Principles) ini sebagai prinsipprinsip kepemimpinan yang ideal yakni prinsip-prinsip kepemimpinannya dapat diterapkan oleh siapapun dengan jabatan apapun sehingga memberikan peluang bagi mereka untuk menjadi seorang pemimpin yang sejati, asalkan mereka memang memiliki komitmen dan ketekunan di dalam mengembangkan pengetahuan dan keterampilan berdasarkan prinsip kepemimpinan ini untuk memimpin atau mempengaruhi orang lain demi tercapainya tujuan (Maxwell, 2013).

Menurut Maxwell (2012), Prinsipprinsip Kepemimpinan 360 Derajat ini diklasifikasikan ke dalam 3 kategori. 
Kategori pertama berisi tentang prinsipprinsip kepemimpinan yang dapat diterapkan seseorang untuk menjadi pemimpin sejati bagi atasan mereka. Kategori kedua berisi tentang prinsipprinsip kepemimpinan yang dapat diterapkan seseorang untuk menjadi pemimpin sejati bagi rekan yang memiliki kedudukan sejajar dengannya. Kategori ketiga terdiri dari prinsip kepemimpinan yang dapat diterapkan seseorang untuk menjadi pemimpin sejati bagi bawahannya. Prinsip-prinsip yang berada di dalam 3 kategori inilah yang peneliti kembangkan untuk menjadi dasar indikator pengujian bagi mahasiswa akuntansi agar mengetahui bagaimana persepsi mereka terhadap kepemimpinan yang ideal.

Sejauh ini banyak perusahaan yang mulai menerapkan Prinsip Kepemimpinan 360 Derajat sebagai dasar pengukuran keefektifan kepemimpinan mereka. Dasar pengukuran berdasarkan Prinsip 360 derajat ini mulai tumbuh dalam popularitas, banyak organisasi menjadi tertarik untuk menyesuaikan penilaian/ pengukuran agar sesuai dengan model kompetensi mereka sendiri. Penilaian 360 Derajat menjadi tulang punggung sebagian besar perusahaan, terutama dalam program pengembangan kepemimpinan mereka. Penilaian ini menjadi populer karena dapat memberikan para pemimpin data empiris yang mengungkapkan bagaimana orang lain memandang kekuatan dan kelemahan mereka (Zenger \& Folkman, 2011).

\section{Pengembangan Hipotesis}

Pengembangan Persepsi Mahasiswa Akuntansi mengenai Kepemimpinan yang Ideal

Kepemimpinan merupakan isu yang saat ini banyak didiskusikan bahkan diteliti.(Almaki, Silong, Idris, \& Abd. Wahat, 2016). Teori kepemimpinan yang mendasari penelitian ini adalah Teori Pertukaran Sosial (SET). Teori ini menyatakan bahwa setiap perilaku karyawan timbul berdasarkan interaksi sosial baik itu yang mendatangkan dampak positif maupun negatif terhadap diri mereka, sehingga ada hubungan antara prestasi kerja karyawan dengan gaya kepemimpinan di perusahaan/ organisasinya (Islam, Rahman, \& Siddiqui, 2018). Penelitian terdahulu yang dilakukan oleh Yıldız, Baştürk, \& Boz pada tahun 2014 mendukung teori ini dan menyatakan bahwa cara memimpin pegawai akan mempengaruhi kinerja usaha mereka (Yıldız, Baştürk, \& Boz, 2014). Di bidang profesi akuntansi, sebuah hasil penelitian yang dilakukan oleh Sun, Gergen, Avila, \& Green pada tahun 2016 menunjukkan bahwa gaya kepemimpinan akan mempengaruhi motivasi para akuntan. Hal ini disebabkan karena perilaku dan karisma seorang pemimpin dengan gaya tertentu akan berkaitan erat dengan kepuasan pegawainya (Sun, Gergen, Avila, \& Green, 2016). Perilaku seseorang dapat dipengaruhi oleh persepsi (Ferguson \& Bargh, 2004). Dengan demikian dapat dikatakan bahwa perilaku kepemimpinan ideal seseorang dapat dipengaruhi oleh persepsi tentang kepemimpinan ideal.

Sebuah penelitian terdahulu menunjukkan bahwa perbedaan persepsi mahasiswa akuntansi tentang etis antara mahasiswa akuntansi yang sudah dan yang belum mengambil mata kuliah etika bisnis cukup signifikan (Wati \& Sudibyo, 2016). Dengan demikian, dapat diduga bahwa pendidikan tentang kepemimpinan ideal di perguruan tinggi juga dapat membantu pembentukan persepsi mahasiswa tentang kepemimpinan yang ideal.

Berdasarkan penjelasan di atas maka hipotesis penelitian ini adalah sebagai berikut:

Ho: Tidak terdapat pengaruh pendidikan kepemimpinan 360 derajat terhadap pembentukan persepsi kepemimpinan 360 derajat mahasiswa akuntansi.

H1: Terdapat pengaruh pendidikan kepemimpinan 360 derajat terhadap pembentukan persepsi kepemimpinan mahasiswa akuntansi. 
Selain itu, penelitian ini juga menganalisis perbedaan pembentukan persepsi mahasiswa akuntansi terhadap prinsip kepemimpinan saat sebelum dan sesudah mengikuti pendidikan tersebut, dengan hipotesis sebagai berikut:

Ho: Tidak terdapat perbedaan pembentukan persepsi kepemimpinan 360 derajat antara mahasiswa akuntansi yang belum menempuh pendidikan kepemimpinan 360 derajat dengan mahasiswa akuntansi yang telah menempuh pendidikan kepemimpinan 360 derajat

H2: Terdapat perbedaan pembentukan persepsi kepemimpinan 360 derajat antara mahasiswa akuntansi yang belum menempuh pendidikan kepemimpinan 360 derajat dengan mahasiswa akuntansi yang telah selesai menempuh pendidikan kepemimpinan 360 derajat.

\section{METODOLOGI PENELITIAN}

Berdasarkan tujuan penelitian, maka jenis penelitian ini masuk ke dalam jenis penelitian deskriptif, asosiatif dan komparatif. Adapun unit analisis atau unit observasi yang digunakan adalah mahasiswa akuntansi. Penelitian ini adalah sebuah studi kasus di Universitas Kristen Maranatha, Bandung. Dengan demikian, populasi dalam penelitian ini adalah seluruh mahasiswa akuntansi yang sedang menempuh studi di Universitas Kristen Maranatha.

Pengambilan sampel dalam penelitian ini menggunakan teknik Non-Probability Sampling serta menggunakan metode Purposive Sampling dalam proses pemilihan sampelnya. Maksud dari penggunaan metode Purposive Sampling ini adalah:

1. Untuk menggambarkan mengenai mitos kepemimpinan dan perbedaan persepsi antara mahasiswa, sampel yang diambil merupakan mahasiswa akuntansi yang belum menempuh pendidikan kepemimpinan 360 derajat dan mahasiswa akuntansi yang sudah menempuh pendidikan kepemimpinan 360 derajat.

2. Untuk menguji pengaruh pendidikan kepemimpinan 360 derajat terhadap pembentukan persepsi kepemimpinan 360 derajat, sampel yang diambil harus mahasiswa akuntansi yang sudah menempuh pendidikan kepemimpinan 360 derajat.

Teknik pengumpulan data yang dilakukan dalam penelitian ini adalah metode survey dengan kuesioner sebagai alat bantu. Teknik pengumpulan data ini dilakukan dengan tujuan untuk memperoleh data primer bagi penelitian ini. Mengenai operasional variabel, penelitian ini memodifikasi 3 sub variabel yang dikembangkan oleh Baartman \& De Bruijn (2011) untuk mengukur variabel Pendidikan Kepemimpinan 360 Derajat sebagai variabel independen. Adapun ketiga sub variabel yang dimaksud meliputi: Pengembangan Pengetahuan, Pengembangan Sikap, serta Pengembangan Keterampilan. (Baartman \& De Bruijn, 2011) yang disajikan di tabel 1.

Tabel 1. Sub Variabel dan Indikator Variabel Pendidikan Kepemimpinan 360

\begin{tabular}{|c|c|c|}
\hline Sub Variabel & Indikator & $\begin{array}{c}\text { Cara } \\
\text { Pengukuran }\end{array}$ \\
\hline \multirow{3}{*}{$\begin{array}{c}\text { Pengembangan } \\
\text { pengetahuan }\end{array}$} & 1. Kurikulum & \multirow{7}{*}{$\begin{array}{c}\text { Kuesioner } \\
\text { dengan } \\
\text { Menggunakan } \\
5 \text { Skala Likert }\end{array}$} \\
\hline & 2. Mata Kuliah & \\
\hline & 3. Fasilitator & \\
\hline \multirow{2}{*}{$\begin{array}{c}\text { Pengembangan } \\
\text { Sikap }\end{array}$} & 1. Pemberian tanggung jawab & \\
\hline & 2. Aturan dan Kebijakan & \\
\hline Pengembangan & 1. Praktik & \\
\hline keterampilan & 2. Situasi Akademik yang Inklusif & \\
\hline
\end{tabular}

Sumber: dimodifikasi dari (Baartman \& De Bruijn, 2011)

Sub variabel yang digunakan untuk mengukur variabel Persepsi Kepemimpinan Mahasiswa Akuntansi meliputi sub variabel Prinsip Memimpin Ke Atas, Prinsip Memimpin ke Samping dan Prinsip Memimpin ke Bawah yang dikembangkan oleh (Maxwell, 2012) dan disajikan di tabel 2 dan tabel 3. 
Tabel 2. Sub Variabel dan Indikator Variabel Persepsi Kepemimpinan Mahasiswa Akuntansi (1)

\begin{tabular}{|c|c|c|}
\hline Sub Variabel & Indikator & $\begin{array}{c}\text { Cara } \\
\text { Pengukuran }\end{array}$ \\
\hline $\begin{array}{l}\text { Penerapan Prinsip } \\
\text { Memimpin } \\
\text { ke Atas } \\
\text { (Maxwell, 2012) }\end{array}$ & $\begin{array}{l}\text { 1. Memimpin Diri Sendiri dengan } \\
\text { Baik } \\
\text { 2. Meringankan Beban Pimpinan } \\
\text { 3. Mau melakukan Hal yang Orang } \\
\text { lain Tak Mau Melakukan } \\
\text { 4. Melakukan lebih dari sekedar } \\
\text { mengelola } \\
\text { 5. Berinvestasi di Ikatan Relasional } \\
\text { 6. Siap Setiap Mengambil Waktu } \\
\text { Atasan } \\
\text { 7. Mengetahui Kapan Harus } \\
\text { Mendorong dan Kapan Harus } \\
\text { Menahan Diri } \\
\text { 8. Menjadi Pemain Yang Diandalkan } \\
\text { 9. Menjadi Pemain yang optimis dan } \\
\text { mau lebih baik }\end{array}$ & $\begin{array}{c}\begin{array}{c}\text { Kuesioner } \\
\text { dengan } \\
\text { Menggunakan }\end{array} \\
5 \text { Skala Likert }\end{array}$ \\
\hline
\end{tabular}

Sumber: (Maxwell, 2012)

Tabel 3. Sub Variabel dan Indikator Variabel Persepsi Kepemimpinan Mahasiswa Akuntansi (2)

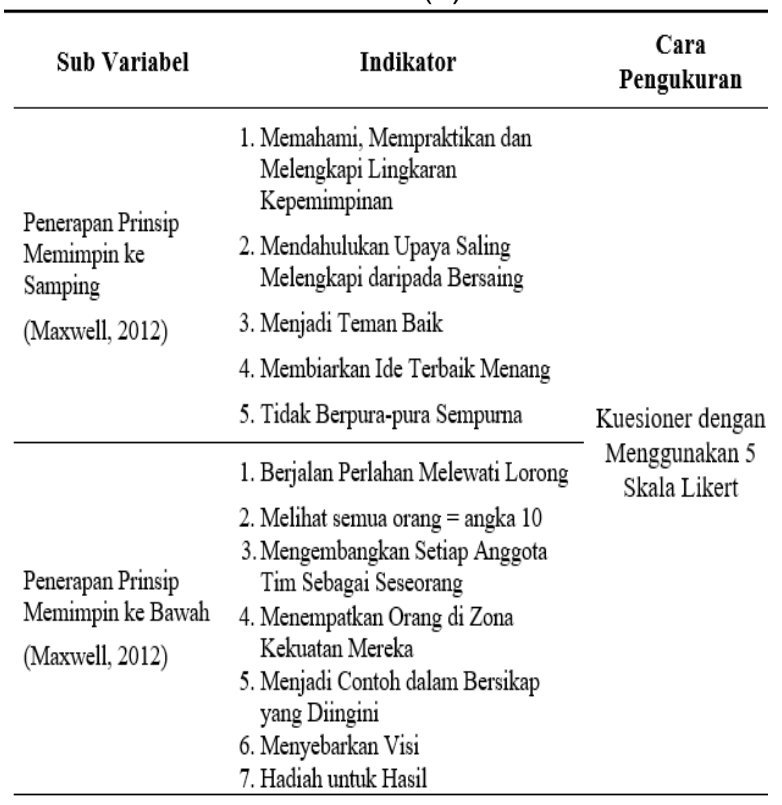

Sumber: (Maxwell, 2012)

Untuk mengetahui pandangan mahasiswa akuntansi terhadap mitos kepemimpinan, maka peneliti menggunakan operasional variabel yang tersaji di tabel 4 .
Tabel 4. Operasional Variabel Mitos Kepemimpinan

\begin{tabular}{|c|c|c|}
\hline Variabel & Indikator & Cara Pengukuran \\
\hline $\begin{array}{c}\text { Pandangan } \\
\text { Mahasiswa| Akuntan } \\
\text { terhadap Mitos } \\
\text { tentang Memimpin } \\
\text { dari Bagian Tengah } \\
\text { Organisasi } \\
\text { (Maxwell, 2012) }\end{array}$ & $\begin{array}{l}\text { 1. Pandangan Mahasiswa Terhadap } \\
\text { Mitos Posisi } \\
\text { 2. Pandangan Mahasiswa Terhadap } \\
\text { Mitos Tujuan } \\
\text { 3. Pandangan Mahasiswa Terhadap } \\
\text { Mitos Pengaruh } \\
\text { 4. Pandangan Mahasiswa Terhadap } \\
\text { Mitos Tak Berpengalaman } \\
\text { 5. Pandangan Mahasiswa Terhadap } \\
\text { Mitos Kebebasan } \\
\text { 6. Pandangan Mahasiswa Terhadap } \\
\text { Mitos Potensi } \\
\text { 7. Pandangan Mahasiswa Terhadap } \\
\text { Mitos Semua atau Tidak Sama } \\
\text { Sekali. }\end{array}$ & $\begin{array}{c}\text { Kuesioner dengan } \\
\text { Menggunakan } 5 \text { Skala } \\
\text { Likert }\end{array}$ \\
\hline
\end{tabular}

Sumber: (Maxwell, 2012)

Penelitian ini menggunakan uji korelasi biavariate untuk menguji validitas instrumen (Sugiyono \& Susanto, 2015) dan menggunakan skor reliabilitas Cronbach's Alpha untuk Kriteria reliabilitas instrumen (Jogiyanto, 2008). Agar dapat mengetahui pandangan mahasiswa akuntansi terhadap mitos kepemimpinan sebagai tujuan penelitian $\mathrm{ke}-1$, penulis menggunakan analisa deskriptif. Menjawab tujuan penelitian ke-2 atau hipotesis ke-1, yakni mengetahui pengaruh pendidikan kepemimpinan 360 derajat terhadap pembentukan persepsi kepemimpinan 360 derajat mahasiswa akuntansi, penulis menggunakan metode Simple Linear Regression. Adapun model regresi linear sederhana dalam penelitian ini adalah (Montgomery, Peck, \& Vining, 2012):

Keterangan:

- $\mathrm{y}=$ variabel dependen

- $\beta 0=$ intercept coefficient, disebut sebagai konstanta

- $\beta 1=$ slope, disebut koefisien regresi

- $\varepsilon=$ error, nilai selisih antara prediksi dengan nilai yang sebenarnya

Untuk memenuhi tujuan penelitian ketiga yakni mengetahui perbedaan pembentukan persepsi kepemimpinan 360 derajat antara mahasiswa yang belum dan yang telah menempuh pendidikan 
Kepemimpinan 360 Derajat, penulis melakukan uji komparatif. Uji komparatif berarti menguji kemampuan generalisasi (signifikansi hasil penelitian) yang berupa perbandingan keadaan variabel dari dua sampel atau lebih (Sugiyono,2017). Penulis menggunakan salah satu teknik statistik yang ada dalam pengujian hipotesis komparatif, disesuaikan dengan hasil uji normalitas terlebih dahulu.

\section{HASIL DAN PEMBAHASAN}

Hasil penelitian menunjukkan bahwa instrumen yang digunakan dalam penelitian ini valid dan reliabel. Seluruh penyataan tentang variabel $X$ dan $Y$ memiliki nilai korelasi pearson diatas 0,3 serta nilai Cronbach's Alpha untuk variable $X$ sebesar 0,842 dan untuk variable $Y$ sebesar 0,866. Untuk dapat menjawab hipotesis pertama dilakukan dengan cara menguji terlebih dahulu variabel $X$ terhadap $Y$ dengan regresi linier sederhana. Sebelum dilakukan pengujian regresi maka perlu diuji normalitas data. Hasil uji normalitas data menunjukkan nilai sig sebesar 0,960 lebih besar dari 0,05, artinya data penelitian berdistribusi normal. Uji regresi selanjutnya dapat dilakukan, hasil uji regresi sederhana dapat dilihat pada tabel 5 .

玉 Tabel 5 Hasil Uji Regresi ANOVA $^{b}$

\begin{tabular}{|l|c|r|r|c|c|}
\hline \multicolumn{1}{|c|}{ Model } & $\begin{array}{c}\text { Sum of } \\
\text { Squares }\end{array}$ & Df & $\begin{array}{c}\text { Mean } \\
\text { Square }\end{array}$ & F & Sig. \\
\hline 1 Regression & 1271.676 & 1 & 1271.676 & 37.167 & $.000^{2}$ \\
Residual & 3353.074 & 98 & 34.215 & & \\
Total & 4624.750 & 99 & & & \\
\hline
\end{tabular}

a. Predictors: (Constant), Pendidikan Kepemimpinan

b. Dependent Variable:

Kepemimpinan

Sumber: Ouput SPSS

Tabel 5 menunjukkan tingkat signifikansi 0.000 lebih kecil dari 0.050 maka hal tersebut menunjukkan bahwa terdapat pengaruh pendidikan kepemimpinan 360 derajat terhadap pembentukan persepsi kepemim-pinan 360 derajat mahasiswa akuntansi. Besaran pengaruh pendidikan kepemimpinan 360 derajat terhadap pembentukan persepsi kepemimpinan 360 derajat mahaiswa akuntansi dapat dilihat pada tabel 6 .

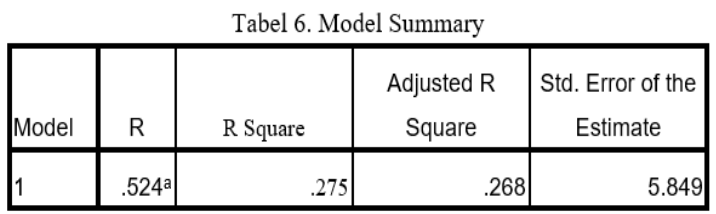

a. Predictors: (Constant), Pendidikan Kepemimpinan

Sumber: Output SPSS

Tabel 6 menunjukkan bahwa nilai $R$ Square sebesar 0,275 atau $27,5 \%$, hal tersebut artinya Pendidikan Kepemimpinan 360 derajat berpengaruh terhadap Pembentukan Persepsi Kepemimpinan 360 Derajat Mahasiswa Akuntansi sebesar $27,5 \%$. Sisanya $72,5 \%$ dipengaruhi oleh faktor lain yang tidak diuji dalam penelitian ini.

Hasil uji komparatif bagi hipotesis kedua yakni untuk mengetahui perbedaan pembentukan persepsi kepemimpinan 360 derajat antara mahasiswa yang belum menempuh pendidikan kepemimpinan 360 derajat dengan yang telah menempuh pendidikan kepemimpinan 360 derajat harus didahului dengan uji normalitas. Pengujian normalitas menggunakan shapiro-wilk dan menunjukkan hasil nilai sig kedua kelompok sebesar 0,000 artinya dibawah 0,05 dan menunjukkan bahwa data tidak berditribusi normal. Jika data tidak berdistribusi normal maka uji komparatif menggunakan uji Mann Whitney. Hasil uji komparatif dapat dilihat pada tabel 7.

Tabel 7. Hasil Uji Komparatif Test Statistics $^{\mathrm{a}}$

\begin{tabular}{|l|r|}
\hline & $\begin{array}{c}\text { Kepemimpinan 360 } \\
\text { Derajat }\end{array}$ \\
\hline Mann-Whitney U & 2204941.500 \\
Wilcoxon W & 4626041.500 \\
Z & -5.689 \\
Asymp. Sig. (2-tailed) & .000 \\
\hline
\end{tabular}

a. Grouping Variable: Kelompok Mahasiswa Akuntansi

Sumber: Output SPSS 
Berdasarkan tabel 7, yang mana nilai sig < 0,05 , maka dapat disimpulkan terdapat perbedaan pembentukan persepsi kepemimpinan 360 derajat antara mahasiswa akuntansi yang belum menempuh pendidikan kepemimpinan 360 derajat dengan mahasiswa akuntansi yang telah menempuh pendidikan kepemimpinan 360 derajat. Perbedaan ini nampak jelas dari sisi persepsi antara mahasiswa yang belum dan telah menempuh pendidikan kepemimpinan 360 derajat terhadap mitos dan cara memimpin ke atasan, rekan dan anak buah mereka. Dari sisi mitos, mahasiswa yang telah menempuh pendidikan kepemimpinan 360 memiliki persepsi kepemimpinan yang lebih ideal berdasarkan konsep Kepemimpinan 360 derajat versi Maxwell (2012). Mereka telah memiliki persepsi bahwa kepemimpinan dapat dikembangkan dan diterapkan tanpa meraih posisi puncak kepemimpinan di organisasinya. Dengan persepsi yang demikian maka mereka diduga lebih memungkinkan untuk menerapkan cara memimpin berbasis 360 Derajat sehingga mereka bukan hanya dapat menjadi pemimpin yang ideal bagi anak buahnya namun juga dapat berupaya memimpin atasan dan rekannya dalam pekerjaan mereka.

Di sini mereka menyadari bahwa sebuah kepemimpinan yang sejati berbicara tentang bagaimana mempengaruhi orang lain tanpa melihat posisi atau kedudukannya di perusahaan. Maka tidaklah heran jika hasil pengujian data menunjukkan bahwa Pendidikan Kepemimpinan 360 Derajat mempengaruhi persepsi mahasiswa Akuntansi mengenai cara mereka memimpin ke atasan, ke rekan yang memiliki posisi setara dan ke rekan yang memiliki posisi di bawah mereka.

Mengenai pandangan mahasiswa Akuntansi terhadap mitos kepemimpinan, hasil pengolahan data menunjukkan bahwa pandangan mahasiswa akuntansi terhadap mitos kepemimpinan berbeda. Mahasiswa akuntansi yang belum menempuh mata kuliah Pendidikan Kepemimpinan 360 Derajat cenderung setuju dengan mitos kepemimpinan, mereka percaya terhadap mitos 1, 3, 4 dan 6. Mahasiswa akuntansi yang belum menempuh mata kuliah pendidikan kepemimpinan 360 derajat setuju bahwa untuk dapat memimpin di perusahaan, maka harus meraih kedudukan tertinggi terlebih dahulu di perusahaan tersebut. Hal tersebut sejalan dengan ungkapan Maxwell (2013), bahwa kekeliruan utama yang sering dilakukan orang saat memahami konsep kepemimpinan yaitu adanya keyakinan bahwa pemimpin akan muncul apabila seseorang memiliki posisi dan gelar tertentu. Mahasiswa juga setuju bahwa mereka harus berusaha meraih kedudukan tertinggi di perusahaan agar orang-orang bersedia untuk mengikuti arahan mereka. Menurut Maxwell (2013) pengaruh harus diperoleh dari usaha, seiring berjalannya waktu seseorang akan mendapatkan level pengaruhnya dari apa yang dikerjakannya, bukan berdasarkan kedudukan tertinggi. Mahasiswa juga setuju bahwa memiliki kedudukan di posisi puncak membuatnya lebih mudah memimpin karena dialah yang memegang kendali. Hal tersebut menunjukkan bahwa mereka tidak menyadari bahwa semakin tinggi mereka naik, semakin besar organisasinya maka semakin banyak faktor yang akan mengendalikan organisasi tersebut, posisi seseorang tidak memberikan orang tersebut kendali penuh dan juga tidak akan melindungi orang tersebut (Maxwell, 2013).

Mahasiswa setuju mereka perlu meraih kedudukan sebagai pemimpin puncak untuk meraih potensinya. Hal tersebut berseberangan dengan ungkapan Maxwell (2013), bahwa seseorang harus berjuang keras untuk mencapai puncak kemampuannya bukan puncak organisasi, masing-masing orang harus bekerja keras untuk mencapai potensinya. Sedangkan untuk mitos 2, 5 dan 7, mahasiswa Akuntansi yang belum menempuh mata kuliah Pendidikan Kepemimpinan 360 Derajat cenderung menjawab kurang setuju. Mahasiswa kurang setuju bahwa untuk dapat belajar dan berlatih menjadi seorang pemimpin sejati harus berusaha meraih kedudukan yang tertinggi di perusahaan. Hal tersebut sejalan dengan ungkapan Maxwell (2013), 
jika seseorang ingin menjadi pemimpin yang sukses, maka orang tersebut harus belajar memimpin sebelum memegang posisi kepemimpinan. Mahasiswa kurang setuju dengan pernyataan saat saya memperoleh posisi di kepemimpinan puncak, tidak ada lagi yang membatasi saya dalam membuat keputusan dan bertindak. Menurut Maxwell (2013), bahwa menjadi seorang pemimpin teratas bukan berarti Anda tidak punya batasan, karena hal tersebut tidak menyingkirkan penutup dari potensi Anda, tanpa mempedulikan pekerjaan yang Anda lakukan atau posisi yang Anda raih, Anda akan tetap memiliki batasan. Mahasiswa kurang setuju dengan pernyataan bahwa menurut saya, lebih baik tidak memimpin orang jika saya tidak berhasil meraih posisi puncak di perusahaan. Menurut Maxwell (2013), seseorang dapat menjadi pemimpin yang lebih baik dimana pun orang tersebut berada, tingkatkan kepemimpinan Anda, maka Anda akan mempengaruhi organisasi Anda, mengubah hidup orang lain, memberikan nilai tambah, Anda akan mempengaruhi orang lain di semua level organisasi tanpa Anda harus mencapai puncak organisasi.

Sedangkan mahasiswa Akuntansi yang telah menempuh mata kuliah pendidikan kepemimpinan 360 derajat cenderung kurang setuju dengan mitos-mitos kepemimpinan, mereka kurang setuju dengan mitos 1, 2, 3, 5, dan 7. Mahasiswa kurang setuju bahwa untuk dapat memimpin di perusahaan, maka harus meraih kedudukan tertinggi terlebih dahulu di perusahaan tersebut. Hal tersebut sejalan dengan pemikiran Maxwell. Menurut Maxwell (2013) bahwa kepemimpinan berhubungan dengan pilihan yang dibuat, bukan tempat yang diduduki; mempengaruhi orang lain adalah masalah disposisi bukan posisi. Seseorang dapat memimpin orang lain dari mana pun di dalam organisasi, hal tersebut yang akan menjadikan organisasi lebih baik (Maxwell, 2013). Mahasiswa kurang setuju bahwa untuk dapat belajar dan berlatih menjadi seorang pemimpin sejati harus berusaha meraih kedudukan yang tertinggi di perusahaan. Hal tersebut sejalan dengan ungkapan Maxwell (2013), bahwa jika Anda ingin sukses, Anda harus mempelajari sebanyak mungkin hal yang bisa Anda pelajari tentang kepemimpinan sebelum Anda memegang posisi kepemim-pinan, jadi jika Anda ingin menjadi seorang pemimpin yang sukses maka belajarlah untuk memimpin sebelum Anda memegang posisi kepemimpinan. Mahasiswa kurang setuju dengan pernyataan bahwa saya harus berusaha meraih kedudukan tertinggi di perusahaan agar orang-orang bersedia untuk mengikuti arahan saya. Sejalan dengan pernyataan Maxwell (2013), bahwa pengaruh harus diperoleh dari usaha, seiring berjalannya waktu seseorang akan menda-patkan level pengaruhnya dari apa yang dikerjakannya, pemimpin yang baik akan mendapatkan peningkatan pengaruh hingga di luar posisi yang dipegangnya. Mahasiswa kurang setuju dengan pernyataan bahwa saat saya memperoleh posisi di kepemimpinan puncak, tidak ada lagi yang membatasi saya dalam membuat keputusan dan bertindak. Menurut Maxwell (2013), banyak orang yang sering keliru bahwa kepemimpinan adalah tiket untuk mendapatkan kebebasan, menjadi seorang pemimpin teratas bukan berarti Anda tidak punya batasan, karena hal tersebut tidak menyingkirkan penutup dari potensi Anda, tanpa mempedulikan pekerjaan yang Anda lakukan atau posisi yang Anda raih, Anda akan tetap memiliki batasan. Mahasiswa kurang setuju bahwa lebih baik tidak memimpin orang jika mereka tidak berhasil meraih posisi puncak di perusahaan. Sejalan dengan pemikiran Maxwell (2013), bahwa seseorang dapat menjadi pemimpin yang lebih baik dimana pun orang tersebut berada, seseorang dapat mempengaruhi orang lain di semua level organisasi tanpa Anda harus mencapai puncak organisasi. Mahasiswa akuntansi yang telah menempuh mata kuliah pendidikan kepemimpinan 360 derajat cenderung setuju dengan mitos 4 dan 6 . Mahasiswa setuju dengan pernyataan bahwa memiliki kedudukan di posisi puncak membuat saya lebih mudah memimpin karena sayalah sang pemegang kendalinya. Menurut Maxwell (2013), tanpa pengalaman sebagai orang teratas di 
suatu organisasi, orang cenderung akan melebih-lebihkan besarnya kendali yang dimilikinya di puncak, tanpa menyadari bahwa banyak faktor yang mengendalikan suatu organisasi. Mahasiswa setuju bahwa mereka perlu meraih kedudukan sebagai pemimpin puncak untuk meraih potensi mereka. Hal tersebut tidak sejalan dengan pemikiran Maxwell (2013), bahwa sesorang harus berjuang keras untuk mencapai puncak potensi diri bukan puncak organisasi, tanpa harus selalu mendapatkan posisi di ruang kantor utama, sesorang dapat memberikan dampak paling besar dari suatu posisi yang bukan posisi pertama.

\section{KESIMPULAN}

Berdasarkan hasil penelitian dan pembahasan, maka penelitian ini memiliki kesimpulan bahwa pandangan mahasiswa Akuntansi yang belum menempuh mata kuliah pendidikan kepemimpinan 360 derajat cenderung setuju dengan mitos kepemimpinan, sedangkan mahasiswa Akuntansi yang telah menempuh mata kuliah pendidikan kepemimpinan 360 derajat cenderung kurang setuju dengan mitos kepemimpinan. Penelitian ini juga menunjukkan bahwa terdapat pengaruh Pendidikan Kepemimpinan 360 derajat terhadap pembentukan persepsi Kepemimpinan 360 Derajat mahasiswa Akuntansi sebesar 27,5\%. Peneliti juga menemukan bahwa terdapat perbedaan pembentukan persepsi kepemimpinan 360 derajat antara mahasiswa akuntansi yang belum pernah menempuh pendidikan kepemimpinan 360 derajat dengan mahasiswa akuntansi yang telah menempuh pendidikan kepemimpinan 360 Derajat.

\section{IMPLIKASI DAN KETERBATASAN}

Penelitian ini memiliki implikasi teoritis dengan menunjukkan hasil penelitian yang mendukung hasil penelitian Wati \& Sudibyo (2016) dimana adanya perbedaan persepsi mahasiswa akuntansi tentang suatu hal antara mahasiswa yang belum dan yang telah mengikuti mata kuliah terkait hal tersebut. Selain itu penelitian ini memiliki implikasi praktis dimana hasil penelitian ini dapat menjadi literatur yang memotivasi dunia pendidikan akuntansi dalam upaya mendesain kurikulum yang mencakup pendidikan kepemimpinan berbasis prinsip Kepemimpinan 360Derajat untuk membentuk persepsi kepemimpinan ideal bagi mahasiswa akuntansi selaku calon akuntan masa depan.

Adapun keterbatasan dari penelitian ini adalah sangat terbatasnya referensi pendukung yang benar-benar menguji pengaruh pendidikan kepemimpinan terhadap pembentukan persepsi kepemimpinan ideal bagi mahasiswa akuntansi. Namun demikian, dengan adanya penelitian ini, diharapkan dapat menjadi referensi yang memotivasi dan membantu peneliti selanjutnya yang tertarik untuk meneliti tentang pendidikan kepemimpinan bagi mahasiswa akuntansi sehingga mampu mendukung upaya Ikatan Akuntan Indonesia dalam menghasilkan akuntan profesional yang mampu memimpin profesinya di masa depan.

\section{REFERENCES}

Almaki, S. H., Silong, A. D., Idris, K., \& Abd. Wahat, N. W. (2016). Understanding of the Meaning of Leadership from the Perspective of Muslim Women Academic Leaders. Journal of Educational and Social Research, $6(2)$. https://doi.org/10.5901/jesr.2016.v6n $2 \mathrm{p} 225$

Arifah, N. (2012). Pengaruh Independensi Auditor, Komitmen Organisasi dan Gaya Kepemimpinan terhadap Kinerja Auditor (Universitas Hasanuddin). Retrieved from http://digilib.unhas.ac.id/opac/detailopac? id=8039

Baartman, L. K. J., \& De Bruijn, E. (2011). Integrating knowledge, Skills and Attitudes: Conceptualising Learning Processes towards Vocational Competence. Educational Research Review,

$6(2)$. 
https://doi.org/10.1016/j.edurev.2011 .03.001

Bloch, J., Brewer, P. C., \& Stout, D. E. (2012). Responding to the leadership needs of the accounting profession: $A$ module for developing a leadership mindset in accounting students. Issues in Accounting Education, 27(2). https://doi.org/10.2308/iace50125

Copeland, M. K. (2015). The Importance of Ethics and Ethical Leadership in the Accounting Profession. Research on Professional Responsibility and Ethics in Accounting, 19. https://doi.org/10.1108/s1574076520150000019005

Ferguson, M. J., \& Bargh, J. A. (2004). How social perception can automatically influence behavior. Trends in Cognitive Sciences, 8(1). https://doi.org/10.1016/j.tics.2003.11. 004

IAI. (2015). Kepemimpinan Akuntan Masa Depan. Retrieved from http://iaiglobal.or.id/beritakegiatan/detailarsip-762

Islam, M., Rahman, M., \& Siddiqui, K. (2018). Leadership Styles Navigate Employee Job Performance. SSRN Electronic Journal, (December). https://doi.org/http://DOI:

10.2139/ssrn.3504262

Jogiyanto. (2008). Pedoman Survei Kuesioner: Mengembangkan Kuesioner, Mengatasi Bias, dan Meningkatkan Respon (1st ed.). Yogyakarta: BPFE.

Keller, L., \& Gollwitzer, P. M. (2017). Mindsets Affect Risk Perception and Risk-Taking Behavior: Illusory Optimism and The BART. Social Psychology, 48(3). https://doi.org/10.1027/18649335/a000304

Maxwell, J. C. (2012). The 360 Degree Leader (5th ed.). Jakarta, Indonesia: PT Bhuana IImu Populer.

Maxwell, J. C. (2013). The 5 levels of Leadership. Surabaya, Indonesia: MIC Publishing.

Mayasari, M., Anjelina, \& Irsutami. (2020). Kompetensi Lulusan Mahasiswa Akuntansi. Journal of Applied
Accounting and Taxation, 5(1).

Montgomery, D. C., Peck, E. A., \& Vining, G. G. (2012). Introduction to linear Regression Analysis (5th ed.). Wiley.

Otara, A. (2011). Perception: A Guide for Managers and Leaders. Journal of Management and Strategy, 2(3). https://doi.org/10.5430/jms.v2n3p21

Rojko, A. (2017). Industry 4.0 Concept: Background and Overview. International Journal of Interactive Mobile Technologies, 11(5). https://doi.org/10.3991/ijim.v11i5.707 2

Rosch, D. M., \& Anthony, M. D. (2012). Leadership Pedagogy: Putting Theory to Practice. New Directions for Student Services, 2012(140). https://doi.org/10.1002/ss.20030

Stanciu, V., \& Bran, F. P. (2015). The Accounting Proffesion in The Digital Era. Calitatea: Acces La Success, 16(S1).

Sugiyono. (2017). Statistik untuk Penelitian. Bandung: Alfabeta.

Sugiyono, \& Susanto, A. (2015). Cara Mudah Belajar SPSS dan Lisrel (1st ed.). Bandung: Alfabeta.

Sun, Y., Gergen, E., Avila, M., \& Green, M. (2016). Leadership and Job Satisfaction: Implications for Leaders of Accountants. American Journal of Industrial and Business Management, 06(03). https://doi.org/10.4236/ajibm.2016.6 3024

Wati, M., \& Sudibyo, B. (2016). Pengaruh Pendidikan Etika Bisnis dan Religiusitas terhadap Persepsi Etis Mahasiswa Akuntansi. Economia, 12(2).

Yıldız, S., Baştürk, F., \& Boz, İ. T. (2014). The Effect of Leadership and Innovativeness on Business Performance. Procedia - Social and Behavioral Sciences, 150. https://doi.org/10.1016/j.sbspro.201 4.09.064

Zenger, J., \& Folkman, J. (2011). The 11 Components of A Best in Class 360 Degree Assessment. Retrieved from https://docplayer.net/10128268-The11-components-of-a-best-in-class360-assessment.html 
